Acta vet. scand. $1970,11,305-317$.

From the Department of Physiology, Veterinary College of Norway, Oslo.

\title{
DETERMINATION AND OCCURRENCE OF FREE AND CONJUGATED HISTAMINE IN URINE OF SHEEP*)
}

By

$\emptyset$. V. Sjaastad

Anrep et al. (1944) were the first to demonstrate adequately the occurrence of histamine in normal urine. Both free histamine and a conjugated form which could be converted to free histamine by acid hydrolysis of the urine were determined. In carnivora, the conjugated form preponderated. Low concentrations of histamine were found in the urine of herbivora $(0.02-0.2 \mu \mathrm{g}$ histamine diphosphate per $\mathrm{ml}$ ) and most of it, if not all, was present as free histamine. The only ruminants included in the investigation of Anrep et al. were the water-buffalo, the camel and the llama.

While the literature offers sparse information about urinary excretion of histamine in ruminants, the levels of histamine in whole blood have been rather well examined. Some of the data obtained have been regarded as being indicative of the role of histamine in the pathogenesis of some diseases (Seekles 1961, Nilsson 1963). The validity of blood analyses as a parameter of changes in the liberation and/or formation of histamine in the body may, however, be strongly questioned. No relationship has been demonstrated between the dose of parenterally injected histamine to man and the blood level of the substance (Rose 1940, Adam 1950). Depending on which species is in question, most of the histamine in whole blood is present either in basophils, in eosinophils or in platelets. It has been demonstrated that the histamine both in basophils and in platelets is partly,

*) Financially supported by the Agricultural Research Council of Norway. 
or entirely, synthesized within the cells (Schayer \& Kobayashi 1956, Lindell et al. 1961). It is therefore probable that the level of histamine in whole blood mainly reflects the number of the specific histamine containing cells. In this connection it is of interest that a high correlation has been demonstrated between the number of basophils and the whole blood level of histamine in man (Valentine et al. 1955, Code $\mathcal{E}$ Mitchell 1957).

Even when histamine is infused at a rate producing pronounced biological effects, the plasma levels do not increase detectably (Adam et al. 1954). A high correlation, however, has been demonstrated between the amounts of histamine injected and the increments in urinary free histamine (Adam et al.). These authors also showed that urinary free histamine probably would be a sensitive indicator on the formation and/or liberation of histamine in the body since injection of histamine in doses just causing detectable biological effect (increased gastric secretion) also resulted in increased levels of urinary free histamine.

Accordingly, in conditions in which involvement of histamine is to be considered determinations of urinary histamine would probably be a better way of approach than histamine analyses of whole blood or plasma. Since the literature gives no information as to the normal excretion of histamine in sheep, such examinations were undertaken.

When histamine is administered by mouth, a low free/conjugated histamine ratio is found in the urine of most species (Anrep et al., Millican et al. 1949). The high free/conjugated histamine ratio found in the urine of ruminants observed by Anrep et al. therefore suggested that urinary histamine does not originate from the digestive tract to any large extent in this group of animals. In sheep histamine seems, however, to be both formed and conjugated by the contents of the forestomachs (Sjaastad, 1967 a, b). Experiments were therefore undertaken to examine, if the ratio free/conjugated histamine in the urine of sheep is similar to that observed by Anrep et al. in other herbivorous animals.

\section{MATERIALS AND METHODS \\ Animals and feeding \\ The 24-hr. urinary excretion of free and conjugated histamine was examined in 6 adult sheep of the Dala breed ( 4 males and}


2 females) and 5 Scottish Blackface ( 1 male and 4 females). The animals were fed at 7 a.m. and 3 p.m., and the daily ration consisted of hay $(0.6-0.7 \mathrm{~kg}$ ), concentrates (about $0.3 \mathrm{~kg}$ ) and kohlrabi (about $0.5 \mathrm{~kg}$ ). Water was freely available.

\section{Collection of urine}

In the male sheep a rubber sling covering the ventral part of the abdominal wall was used. Before securing the sling, the wool was clipped and the abdominal wall properly washed. From the most ventral part of the sling a plastic tube led to a 2-1 plastic flask containing $250 \mathrm{ml}$ of $\mathrm{N}-\mathrm{HCl}$, usually providing a $\mathrm{pH}$ lower than 2.0. Urine specimens with $\mathrm{pH}$ higher than 3.0 were discarded. Preliminary experiments showed that urine could be stored. at $20^{\circ} \mathrm{C}$ and a low $\mathrm{pH}$ for $24 \mathrm{hrs}$. without any significant change in histamine activity. In the females, urine was collected by housing the sheep in metabolism cages of the type described by Duthie (1959).

\section{Determination of histamine}

For the determination of free and total (free + conjugated) histamine the method of Dunér \& Pernow (1956) was used with some minor modifications:

Free histamine was determined essentially in the same way as free histamine in rumen liquor (Sjaastad 1967 a). The method is briefly as follows: After filtration, the $\mathrm{pH}$ of the urine was adjusted to 6.5 (Merck's indicator paper) and 100-ml samples were passed through Amberlite IRC-50 columns $(150 \times 10 \mathrm{~mm}$, 4-6 ml/min.). The columns were then washed with $2 \times 25 \mathrm{ml}$ of distilled water. Precautions were taken that the resin was always covered by a layer of fluid. Histamine was eluted with $1.2 \mathrm{~N}-\mathrm{HCl}$ (approximately $0.2 \mathrm{ml} / \mathrm{min}$.), the volume of acid (in $\mathrm{ml}$ ) being calculated by multiplying the height of the resin (in $\mathbf{c m}$ ) after washing with distilled water, by a factor of 0.95 . When the level of $1.2 \mathrm{~N}-\mathrm{HCl}$ had sunk to the top of the resin, $10 \mathrm{ml}$ of $0.01 \mathrm{~N}-\mathrm{HCl}$ was added and collection of the eluate started. The $\mathrm{pH}$ of the effluent was checked at frequent intervals and the eluates discarded until the check prior to the change to an acid $\mathrm{pH}$. When this change in $\mathrm{pH}$ had taken place, the flow rate was increased to about $0.5 \mathrm{ml} / \mathrm{min}$. Elution was then continued until all acid had passed through the resin. 
Total histamine (free + conjugated). After adjusting the $\mathrm{pH}$ to $6.5,100 \mathrm{ml}$ of the urine specimens were precipitated with $200 \mathrm{ml}$ of acetone (technical grade). The mixtures were shaken and then filtered into evaporation flasks which contained $7 \mathrm{ml}$ of $2 \mathrm{~N}-\mathrm{HCl}$ providing a $\mathrm{pH}$ of the filtrates lower than 3.0. The filtrates were evaporated ex vacuo on a boiling water bath until 2-3 $\mathrm{ml}$ were left, whereafter the residues were dissolved in $10+5+5 \mathrm{ml}$ conc. $\mathrm{HCl}$ and boiled under reflux for $2 \mathrm{hrs}$. The hydrolysates were evaporated to complete dryness ex vacuo. The residues were dissolved in approximately $50 \mathrm{ml}$ of distilled water, and after adjusting the $\mathrm{pH}$ to 6.5 (Radiometer, Copenhagen) the samples were centrifuged at $4000 \times \mathrm{g}$ for $10 \mathrm{~min}$. Distilled water was added to the supernatant fluid to a final volume of $100 \mathrm{ml}$, and histamine was extracted by passage through Amberlite IRC50 columns $(200 \times 10 \mathrm{~mm})$. After washing with distilled water, $1.2 \mathrm{~N}-\mathrm{HCl}$ was added to the columns, followed by $15 \mathrm{ml}$ of 0.01 $\mathrm{N}-\mathrm{HCl}$. The amounts of $1.2 \mathrm{~N}-\mathrm{HCl}$ were calculated as for free histamine. A coloured band was usually seen in front of the acidified part of the resin. When this band reached the bottom of the resin, the collection of the eluate was started. When no coloured band was present, the $\mathrm{pH}$ was checked with frequent intervals after the addition of $0.01 \mathrm{~N}-\mathrm{HCl}$. Collection of the eluate was then started from the time of the check prior to the change to an acid $\mathrm{pH}$.

The acid eluates of free and total histamine were stored at $4{ }^{\circ} \mathrm{C}$ until determination of histamine concentration; this was carried out not later than 5 days after the extraction procedure. The histamine concentrations of the neutralized eluates were estimated on guinea-pig ileum suspended in an organ bath $(6 \mathrm{ml})$ containing Tyrode's solution and atropine $(0.05 \mu \mathrm{g} / \mathrm{ml})$. The determination of the unknown was done by bracketing between histamine standards, the standards being chosen so they usually differed less than $15 \%$ in histamine content. The coefficient of variation of the method was calculated from the formula $\sqrt{\frac{\Sigma d^{2}}{2(\bar{n}-1)}} \cdot \frac{100}{\bar{x}}$, where $d$ is the difference between duplicate determinations, $n$ the number of duplicate determinations and $\bar{x}$ the mean 24-hrs. excretion of free or conjugated histamine. In 20 specimens of urine (free histamine 5.3-12.7 $\mu \mathrm{g}$ base $/ 24 \mathrm{hrs}$., conjugated histamine $6.7-20.6 \mu \mathrm{g} / 24 \mathrm{hrs}$.) the coefficients of variation of the methods for estimation of free and conjugated 
histamine were 6.3 and $12.0 \%$, respectively. The histamine values are recorded in terms of the base, they represent the mean of duplicates and they are uncorrected for losses due to the extraction procedure.

Amberlite IRC-50 (Standard grade) was obtained from British Drug Houses Ltd., England. Batches of the resin were prepared according to the principle outlined by Bergström \& Hansson (1951). After transfer of the resin to the ion-exchange columns, it was treated with $0.5 \mathrm{M} \mathrm{Na}$-phosphate buffer ( $\mathrm{ph} 6.5$ ) until the $\mathrm{pH}$ of the effluent from the columns was the same as that of the buffer.

Histamine diphosphate and $\mathrm{N}$-acetylhistamine were bought from Nutritional Biochemicals Corp., Cleveland, Ohio, USA.

Antihistamine Allergin ${ }^{\circledR}$ (diphenhydramine chloride) was purchased from Nyegaard \& Co., A/S, Oslo, Norway.

L-histidine-monochloride-monohydrate was obtained from Sigma Chemical Co., St. Louis, USA.

\section{RESULTS}

Free histamine (control of method)

Adsorption of histamine at different flow rates of urine through the resin. $100 \mathrm{ml}$ samples of urine adjusted to $\mathrm{pH} 6.5$, to which histamine had been added (100 $\mu \mathrm{g}$ histamine diphosphate $/ \mathrm{ml}$ ), were passed through the resin at different flow rates. The histamine concentration of the percolate was assayed directly on guinea-pig ileum. At flow rates of $4-6 \mathrm{ml} / \mathrm{min}$., as used in this study, almost all histamine was adsorbed to the resin (Fig. 1). When aqueous solutions of histamine were passed through the resin, about $98 \%$ of the histamine was adsorbed even at flow rates of $25 \mathrm{ml} / \mathrm{min}$.

Recovery of added histamine using different amounts of ionexchange resin. Histamine diphosphate $(5-100 \mu \mathrm{g})$ was added to 100-ml samples of urine and adsorbed on Amberlite IRC-50 columns of different heights $(6,10$ and $15 \mathrm{~cm})$. With columns of $6 \mathrm{~cm}$ the recovery was low and variable (Table 1). By increasing the height of the resin to $15 \mathrm{~cm}$, higher and less variable recovery was obtained (Table 1 ). The recovery, when 5 or $10 \mu \mathrm{g}$ histamine diphosphate were adsorbed on $10 \mathrm{~cm}$ columns (7 expts.), was not significantly lower than when $100 \mu \mathrm{g}$ (6 expts.) were added $(72.0 \pm 15.9$ and $82.5 \pm 4.0 \%$, respectively, $\mathrm{P}>0.05)$.

Conjugated histamine (control of method)

Temperature during hydrolysis. By the method of Dunér $\mathfrak{A}$ Pernow (1956) conjugated histamine is converted to free hista- 


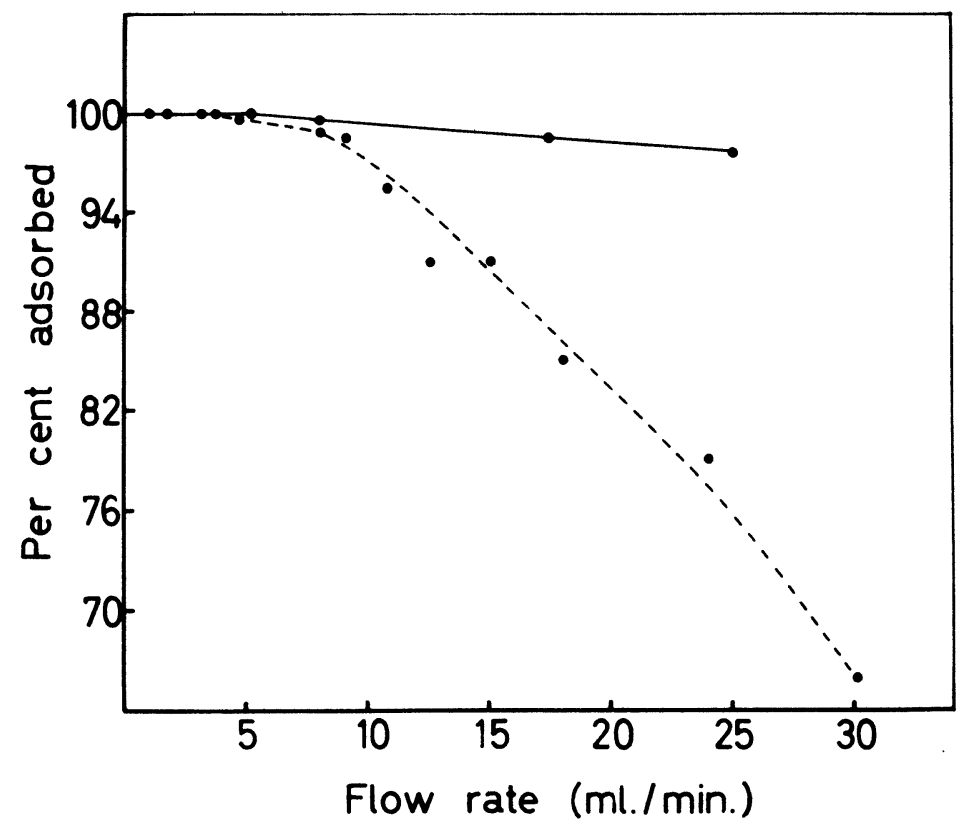

Fig u r e 1. Adsorption of histamine on Amberlite IRC-50 columns $(150 \times 10 \mathrm{~mm})$ at different flow rates of urine $\left(\cdot-{ }^{\prime} \cdot\right)$ and distilled water (.....) $100 \mathrm{ml}$ of each. $100 \mu \mathrm{g}$ histamine diphosphate per ml were added. The histamine concentration of the percolate was assayed directly on isolated guinea-pig ileum.

Table 1. Recovery percentage of added histamine using different amounts of ion-exchange resin. Histamine added: $5-100 \mu \mathrm{g}$ histamine diphosphate.

\begin{tabular}{lccc}
\hline & \multicolumn{3}{c}{$\begin{array}{c}\text { Size of resin } \\
(\mathrm{mm})\end{array}$} \\
\cline { 2 - 4 } & $60 \times 10$ & $100 \times 10$ & $150 \times 10$ \\
\hline $\mathrm{n}$ & 19 & 15 & 12 \\
mean $\pm \mathrm{s}$ & $52.7 \pm 15.4$ & $79.5 \pm 12.5$ & $88.8 \pm 5.8$ \\
\hline
\end{tabular}

mine by hydrolysing concentrated and acetone-treated urine samples under reflux in $10 \mathrm{~N}-\mathrm{HCl}$ on a boiling water bath for $1 \frac{1}{2} \mathrm{hrs}$. In our hands this procedure resulted in a low recovery of $\mathrm{N}$-acetylhistamine $(40-80 \mu \mathrm{g})$ added to urine $(29.7 \pm 5.1 \%$, 10 expts.). Boiling under reflux on a hot plate (temperature $\left.107-112^{\circ} \mathrm{C}\right)$ greatly increased the recovery $(79.4 \pm 12.5 \%, 7$ expts.). 
Decarboxylation of histidine takes place at temperatures above $145^{\circ} \mathrm{C}$. Although such temperatures were never registered during hydrolysis in the present experiment, it is conceivable that they might occur locally if charring takes place. In 2 experiments $10 \mathrm{mg}$ of L-histidine were added to urine extracts before hydrolysis. The quantities of total histamine in these samples did not differ from that in 2 controls. No detectable decarboxylation of histidine had thus taken place in these experiments.

Loss of free histamine during evaporation. The method of Dunér \& Pernow for conjugated histamine involves evaporation of acetone-treated urine to dryness ex vacuo at $\mathrm{pH} 6.5$ in a boiling water bath. Since histamine is unstable at alkaline $\mathrm{pH}$, some free histamine might be lost during this stage of the procedure. The effect of $\mathrm{pH}$ on the stability of added histamine diphosphate $(200 \mu \mathrm{g})$ during evaporation was therefore examined in 3 experiments. Losses of free histamine seemed to take place when the evaporation was carried out at $\mathrm{pH} 6.5$ (Table 2). To avoid losses, the $\mathrm{pH}$ should be kept as low as 3.0 (Table 2).

$\mathrm{T} \mathrm{a} \mathrm{b} \mathrm{l} \mathrm{e} \mathrm{2.} \mathrm{The} \mathrm{effect} \mathrm{of} \mathrm{pH}$ on the stability of free histamine during evaporation of acetone-treated urine. Histamine added per $100 \mathrm{ml}$ urine: $200 \mu \mathrm{g}$ histamine diphosphate. The $\mathrm{pH}$ of the treated urine was adjusted with $\mathrm{N}-\mathrm{NaOH}$ and evaporated ex vacuo at $80-90^{\circ} \mathrm{C}$. The residues were dissolved in Tyrode's solution and neutralized, whereupon the histamine content was assayed directly on guinea-pig ileum. The figures are obtained by subtracting the blind values for free histamine (determined by ion-exchange chromatography).

\begin{tabular}{|c|c|c|c|c|c|}
\hline \multirow{2}{*}{$\begin{array}{c}\text { Expt. } \\
\text { no. }\end{array}$} & \multicolumn{5}{|c|}{ Histamine found after evaporation ( $\%$ of added) } \\
\hline & pH 6.5 & pH 5 & pH 4 & pH 3 & pH 2 \\
\hline 1 & 69,71 & 75 & 83 & 95 & 94 \\
\hline 2 & 63,62 & 67 & 74 & 98 & 100 \\
\hline 3 & 67 & 72 & 78 & 97 & 96 \\
\hline
\end{tabular}

Recovery of N-acetylhistamine. Conjugated histamine in urine is believed to be identical to $\mathrm{N}$-acetylhistamine (Tabor \& Mosettig 1949). The recovery of $\mathrm{N}$-acetylhistamine added to urine was increased by increasing the height of the columns from 6 to $20 \mathrm{~cm}$ (Table 3 ). The recovery was not further increased by extending the period of hydrolysis or by further increasing the amount of resin. 
Table 3. Recovery percentage of added $\mathrm{N}$-acetylhistamine using different amounts of ion-exchange resin. $\mathrm{N}$-acetylhistamine added: $40-400 \mu \mathrm{g} / 100 \mathrm{ml}$ of urine.

\begin{tabular}{lccc}
\hline & \multicolumn{3}{c}{$\begin{array}{c}\text { Size of resin } \\
(\mathrm{mm})\end{array}$} \\
\cline { 2 - 5 } & $60 \times 10$ & $120 \times 10$ & $200 \times 10$ \\
$\mathrm{n}$ & 15 & 12 & 50 \\
mean $\pm \mathrm{s}$ & $51.3 \pm 7.2$ & $66.7 \pm 9.6$ & $77.3 \pm 9.6$ \\
\hline
\end{tabular}

Excretion of free and conjugated histamine in the urine of normal sheep

In 11 healthy adult sheep the 24-hrs. urinary excretion of free and conjugated histamine were $9.8 \pm 9.0 \mu \mathrm{g}$ histamine base/ $24 \mathrm{hrs}$. and $15.1 \pm 9.9 \mu \mathrm{g} / 24 \mathrm{hrs}$., respectively (Table 4 ). There was no obvious difference in the excretion in the males and females.

Table 4. The urinary excretion of free and conjugated histamine in 11 healthy sheep.

\begin{tabular}{cccc}
\hline Sex & $\begin{array}{c}\text { Sheep } \\
\text { no. }\end{array}$ & \multicolumn{2}{c}{$\begin{array}{c}\text { Urinary excretion of histamine } \\
(\mu \mathrm{g} \text { base } / \mathbf{2 4} \text { hrs. })\end{array}$} \\
\cline { 3 - 4 } free & conjugated \\
m & 1 & 9.5 & 13.6 \\
f & 2 & 34.2 & 37.1 \\
m & 3 & 10.4 & 26.1 \\
m & 4 & 5.3 & 13.5 \\
f & 5 & 4.2 & 8.9 \\
m & 7 & 2.1 & 2.9 \\
f & 8 & 8.8 & 19.3 \\
f & 9 & 10.9 & 15.2 \\
f & 10 & 14.5 & 16.4 \\
f & 11 & 4.5 & 9.1 \\
mean $\pm \mathrm{s}$ & 3.0 & 3.9 \\
\hline
\end{tabular}

In 1 sheep (no. 2, Table 4) the excretion of both free and conjugated histamine deviated much from the figures obtained for the rest of the group. However, when re-examined about 1 year later, the excretion of both free and conjugated histamine 
in this sheep $(9.3 \mu \mathrm{g} / 24 \mathrm{hrs}$. and $20.4 \mu \mathrm{g} / 24 \mathrm{hrs}$., respectively) fell within the range obtained for the remaining animals.

In 3 animals examined for a longer period of time, the intraindividual variation in histamine excretion seemed to be of a similar order of magnitude as that encountered between animals (Table 5).

T a b l e 5. Intraindividual variation of urinary excretion of free and conjugated histamine in 3 sheep. The study was done over a period of $1 \frac{1 / 2}{2}$ years.

\begin{tabular}{ccccc}
\hline Sheep & $\begin{array}{c}\text { Number } \\
\text { of } \\
\text { expts. }\end{array}$ & \multicolumn{2}{c}{ Urinary excretion of histamine $(\mu \mathrm{g}$ base/24 hrs.) } \\
\cline { 3 - 5 } & $\begin{array}{c}\text { free histamine } \\
\text { (mean, s and range) }\end{array}$ & $\begin{array}{c}\text { conjugated histamine } \\
\text { (mean, s and range) }\end{array}$ \\
\hline 4 & 19 & $5.3 \pm 2.0$ & $(1.3-9.9)$ & $13.5 \pm 6.7 \quad(2.1-22.2)$ \\
5 & 13 & $4.2 \pm 2.2$ & $(1.0-9.3)$ & $8.9 \pm 6.1 \quad(3.6-24.2)$ \\
7 & 7 & $8.8 \pm 4.3(14.5-14.8)$ & $19.3 \pm 16.3 \quad(4.7-48.3)$ \\
\hline
\end{tabular}

The mean conjugated/free histamine ratio in the present material was 1.5 (range $1.1-2.6$, Table 4 ). If the values for free and conjugated histamine had been corrected for analytical losses, the mean conjugated/free ratio in the urine would have been 1.7 .

\section{DISCUSSION}

Anrep et al. (1944) found that the urine of herbivorous animals contained substances which by the method used by them, interfered with the biological assay of histamine. By modifying the method of Duner \& Pernow (1956), free histamine in the urine of sheep could be determined with satisfactory reproducibility and on an average about $90 \%$ of histamine added to urine was recovered. However, in order to arrive at an accurate estimate of the recovery of histamine added to urine, $5 \mu \mathrm{g}$ or more of histamine diphosphate were added to each $100 \mathrm{ml}$ aliquot of the urine specimens. The concentration of free histamine naturally present in the urine of sheep is, on the other hand, sometimes lower than $1 \mu \mathrm{g}$ histamine diphosphate $/ 100 \mathrm{ml}$ of urine. Larger volumes of urine extracts had therefore to be added to the organ bath to obtain desired responses when the normal excretion was determined, than when the recovery of added histamine was examined. It might thus be wrong to conclude 
that histamine naturally present in the urine is equally accurately determined as histamine added to urine. The true values for histamine in the urine of sheep might therefore be somewhat higher than the present results indicate. However, occasional addition of internal standards of histamine to the urine extracts showed that they did not contain interfering substances in amounts greatly disturbing the bioassay.

In contrast to the findings of Anrep et al. in other herbivorous animals, the sheep examined in the present study excreted larger amounts of conjugated histamine than of free histamine. Generally, it is believed that conjugated histamine found in the urine is of dual origin, it is partly being formed by bacteria in the intestines (Urbach 1949, Wilson 1954) and partly it is being formed in tissues (Millican 1953, Wilson, Schayer 1956). Conjugated histamine consists partly, or entirely, of N-acetylhistamine (Tabor \& Mosettig 1949). In sheep conjugated metabolites of $\mathrm{C}^{14}$-histamine are not detectable in the urine subsequent to intravenous injection of $\mathrm{C}^{14}$-histamine (Eliassen). Disregarding the possibility that endogenous histamine is treated differently from intravenously injected histamine, this fact indicates that conjugated histamine in urine of sheep is mostly, or entirely of exogenous origin. Histamine formed and conjugated by the contents in the forestomachs (Sjaastad $1967 \mathrm{a}, \mathrm{b}$ ) does probably to a considerable extent contribute to the conjugated histamine in the urine. Since the in vitro formation of histamine by rumen contents was increased by addition of L-histidine (Sjaastad $1967 \mathrm{a})$, the amounts of conjugated histamine in the urine are probably to some extent depending on the amount of protein in the diet fed.

In vitro experiments have indicated that small amounts of conjugated histamine (not necessarily $\mathrm{N}$-acetylhistamine) are formed in the liver of sheep (Sjaastad $1967 \mathrm{c}$ ). The failure to demonstrate the presence of conjugated metabolites in the urine after injection of $\mathrm{C}^{14}$-histamine might be due to the possibility that the amounts of conjugated histamine formed in vivo are too small to be detected in the urine by the technique used by Eliassen.

Orally administered histamine does not substantially increase the amounts of free histamine in the urine (Sjaastad $1967 \mathrm{~d}$ ). With some reservations for the possibility that histamine formed 
in the digestive tract is treated differently from histamine given by mouth, this fact suggests that most urinary free histamine in sheep originates from histamine formed in the tissues.

\section{ACKNOWLEDGMENTS}

The technical assistance of Mrs. Solvaar Eliassen is highly appreciated.

\section{REFERENCES}

Adam, H. M.: Excretion of histamine in human urine. Quart. J. exp. Physiol. 1950, 35, 281-293.

Adam, H. M., W. I. Card, M. J. Ridell, M. Roberts \& J. A. Strong: The effect of intravenous infusions of histamine of the urinary histamine and on gastric secretion in man. Brit. J. Pharmacol. 1954, 9, 62-67.

Anrep, G. V., M. S. Ayadi, G. S. Barsoum, J. R. Smith \& M. M. Talaat: The excretion of histamine in urine. J. Physiol. (Lond.) 1944, $103,155-174$.

Bergström, S. \& G. Hansson: The use of Amberlite IRC-50 for the purification of adrenaline and histamine. Acta physiol. scand. 1951, 22, 87-92.

Code, C. F. \& R. G. Mitchell: Histamine eosinophils and basophils in the blood. J. Physiol. (Lond.) 1957, 136, 449-468.

Dunér, H. \& B. Pernow: Urinary excretion of histamine in healthy human subjects. Scand. J. clin. Lab. Invest. 1956, 18, 296-303.

Duthie, I. F.: A sheep metabolic cage for mineral balance and radioisotope experiments. Lab. Pract. 1959, 8, 408—411, 414.

Eliassen, $K$. A.: To be published.

Lindell, S. E., H. Rorsman \& H. Westling: Histamine formation in human blood. Acta allerg. (Kbh.) 1961, 16, 216-227.

Millican, $R$. C.: The acetylation of histamine in normal and enterectomized rats. Arch. Biochem. 1953, 42, 399-405.

Millican, R. C., S. M. Rosenthal \& H. Tabor: On the metabolism of histamine. A. Urinary excretion following oral administration. B. Conjugation in vitro. J. Pharmacol. exp. Ther. 1949, 97, 4-13.

Nilsson, S. A.: Clinical, morphological and experimental studies of laminitis in cattle. Acta vet. scand. 1963, 4, Suppl. 1.

Rose, B.: Production of symptoms by subcutaneous injection of histamine without increase of the blood histamine. Science 1940, $92,454$.

Schayer, $R$. W.: The metabolism of histamine in various species. Brit. J. Pharmacol. 1956, 11, 472-476.

Schayer, R. W. \& Y. Kobayashi: Histidine decarboxylase and histamine binding in rabbit platelets. Proc. Soc. exp. Biol. (N.Y.) 1956, 92, 653--655. 
Seekles, L.: Über Weidetetanien. (On grasstetanies). 4. Kongress der Deutschen Vet. Med. Ges., Bad Nauheim 1961, 733-743.

Sjaastad, $\emptyset$. V.: Determination and occurrence of histamine in rumen liquor of sheep. Acta vet. scand. 1967 a, 8, 50-70.

Sjaastad, $\emptyset$. V.: Fate of ingested histamine in sheep. I. Disappearance from the rumen. Acta vet. scand. $1967 \mathrm{~b}, 8,157-175$.

Sjaastad, $\emptyset$. V.: The in vitro catabolism of histamine by sheep liver tissue. Acta physiol. scand. 1967 c, 71, 6-15.

Sjaastad, $\emptyset$. V.: Fate of ingested histamine in sheep. II. Faecal and urinary excretion. Acta vet. scand. $1967 \mathrm{~d}, 8,176-183$.

Tabor, H. \& E. Mosettig: Isolation of acetylhistamine from urine following oral administration of histamine. J. biol. Chem. 1949, $180,7.03-7.06$.

Urbach, $K . F .:$ Nature and probable origin of conjugated histamine excreted after ingestion of histamine. Proc. Soc. exp. Biol. (N.Y.) 1949, 70, 146-152.

Valentine, W. N., J. S. Lawrence, M. L. Pearce \& W. S. Beck: The relationship of the basophil to blood histamine in man. Blood 1955, 10, 154-159.

Wilson, C. W. M.: Factors influencing the urinary excretion of histamine in the rat. J. Physiol. (Lond.) 1954, 126, 141-154.

\section{SUMMARY}

1. By modifying the method of Duner \& Pernow (1956) the urinary excretion of free and conjugated histamine was examined in 11 healthy adult sheep.

2. The mean excretion of free histamine was $9.8 \pm 9.0$ (s) $\mu \mathrm{g}$ base $/ 24 \mathrm{hrs}$. (uncorrected for losses during extraction). When individual means were used, the range was: $2.1-34.2 \mu \mathrm{g}$ base $/ 24 \mathrm{hrs}$. The intraindividual variations were of the same order as the interindividual variations.

3. The mean excretion of conjugated histamine was equivalent to $15.1 \pm 9.9$ (s) $\mu \mathrm{g}$ histamine base $/ 24 \mathrm{hrs}$. In all animals the ratio conjugated/free histamine was above 1 . The interindividual as well as the intraindividual variation for conjugated histamine was of the same order as for free histamine.

\section{SAMMENDRAG}

Bestemmelse og forekomst av fri og konjugert histamin i urin fra sau (får).

1. Utskillelsen av fri og konjugert histamin med urinen hos $\mathbf{1 1}$ voksne, normale sauer ble unders $\varnothing$ kt med en metode etter Dunér \& Pernow (1956) noe modifisert.

2. Ekskresjonen av fritt histamin var i middel $9.8 \pm 9.0$ (s) $\mu \mathrm{g}$ base/24 timer (ukorrigert for tap under ekstraksjonen). De indivi- 
duelle middelverdier varierte fra 2.1 til $34.2 \mu \mathrm{g}$ base/24 timer. De intraindividuelle og de interindividuelle variasjoner var av samme størrelsesorden.

3. Utskillelsen av konjugert histamin var i middel ekvivalent med $15.1 \pm 9.9$ (s) $\mu \mathrm{g}$ histamin-base/24 timer. Hos alle dyr var kvotienten konjugert/fri histamin større enn 1. Både de intra- og interindividuelle variasjoner for konjugert histamin var av samme st $\varnothing \mathrm{r}$ relsesorden som for fri histamin.

(Received November 5, 1969). 